\title{
Anxiety level of college going students across the gender
}

\author{
RUBI VERMA AND MAMTA KUMARI
}

Received: 30.05.2014; Accepted: 28.11 .2014

See end of the paper for authors' affiliations

\section{MAMTA KUMARI}

Department of Human

Development, Ethelind School of

Home Science, Sam

Higginbottom Institute of

Agriculture, Technology and

Sciences, ALLAHABAD (U.P.)

INDIA

Email: missmamtu@gmail.com
ABSTRACT : Anxiety is a common condition noticed in people of all age groups. It may be caused by a physical condition, mental condition, effects of drugs or due to a combination of these. The concept of anxiety is characterized most commonly or a diffused, unpleasant vague sense of comprehension, often accompanied by autonomic symptoms such as headache, perspiration, palpitation tightness of the chest, mild stomach discomfort, and restlessness, indicated by an inability to sit or stand still for a long time. (Sadock and Sadock, 2007). The study aimed to assess the anxiety level of college going students across gender. Two colleges namely, Kamla Nehru Institute of Physical and Social Sciences College and Ganpat Sahay college were selected from Sultanpur city. For the collection of information, 60 students were selected randomly from that college. These 60 college going students were divided into two categories in which 30 boys and 30 girls were included. The questionnaire schedule was used to elicit the general information pertaining to respondents. For specific information, Sinha's Comprehensive Anxiety test (1971) developed by A.K.P. Sinha and L.N.K. Sinha was used in this study. The results were carried out through the frequency and percentage method. The findings of study concluded that most of the respondents $(63.33 \%)$ had extremely high anxiety.

KEY WORDS: Anxiety, College students, Anxiety test

口 HOW TO CITE THIS PAPER : Verma, Rubi and Kumari, Mamta (2014). Anxiety level of college going students across the gender. Asian J. Home Sci., 9 (2) : 658-659. 